\title{
Social cost-benefit analysis of hydrogen mobility in Europe
}

\author{
Carmen Cantuarias-Villessuzanne ${ }^{\mathrm{a}, *}$, Benno Weinberger ${ }^{\mathrm{a}}$, Leonardo Roses ${ }^{\mathrm{b}}$, \\ Alexis Vignes ${ }^{\mathrm{a}}$, Jean-Marc Brignon ${ }^{\mathrm{a}}$ \\ ${ }^{a}$ INERIS, Parc Technologique ALATA BP 2, 60550 Verneuil-en-Halatte, France. \\ ${ }^{b}$ HyGear B.V., Industry Park De Kleefse Waard, Arnhem, The Netherlands.
}

\begin{abstract}
The deployment of hydrogen technologies in the energy mix and the use of hydrogen fuel cell vehicles (FCV) are expected to significantly reduce European greenhouse emissions. We carry out a social cost-benefit analysis to estimate the period of socio-economic conversion, period for which the replacement of gasoline internal combustion engine vehicles (ICEV) by FCV becomes socio-economically profitable. In this study, we considered a hydrogen production mix of five technologies: natural gas reforming processes with or without carbon capture and storage, electrolysis, biogas processes and on-site production.

We estimate two external costs: the abatement cost of $\mathrm{CO}_{2}$ through FCV and the use of non-renewable resources in the manufacture of fuel cells by measuring platinum depletion. We forecast that carbon market could finance approximately $10 \%$ of the deployment cost of hydrogen-based transport and that an early economic conversion could be targeted for FCV. Almost ten years could be saved by considering externalities. ${ }^{1}$
\end{abstract}

Keywords: Hydrogen economy, hydrogen fuel cell vehicles, social cost-benefit analysis, external costs, carbon abatement cost, platinum depletion.

\footnotetext{
${ }^{*}$ Corresponding author

Email address: carmen.cantuarias@ineris.fr (Carmen Cantuarias-Villessuzanne)

${ }^{1}$ Abbreviations used: CBA, cost-benefit analysis; CCS, carbon capture and storage; ETP, Energy Technology Perspectives; FCV, fuel cell vehicles; HRS, hydrogen refueling stations; ICEV, internal combustion engine vehicles; LCA, life cycle assessment; NPV, net present value; SMR, steam methane reforming; SNPV, social net present value; TCO, total cost of ownership.
} 


\section{Introduction}

Several studies have explored the potential technological innovations, the associated economic conditions and prospective scenarios for the deployment of new power-trains in Europe [1, 2, 3, 4, 5].

Hydrogen requires a comprehensive support scheme that bridges the gap between three main dimensions: (i) market requirements, (ii) sustainability and climate requirements, and (iii) hydrogen technology development [6].

(i) Market requirements for hydrogen as energy carrier is tackled by the following points: competitive price compared to other environmentally friendly energy carrier like batteries; refuelling infrastructure permitting the autonomy range requierd by users; fast and easy storage process enabling a great autonomy for mobility; and safety levels equal to or better than carbonized energy sources. Acceptance of this new use of hydrogen is also related to its safety. Though the different accidental risks of hydrogen are well known, the risks related to the industrial use and the private use of hydrogen cannot be compared, because the private users do not have the same restrictions as professional users.

(ii) Sustainability and climate requirements for hydrogen energy have to fit the political objectives initiated by the European Commission and the different Member States; eg. the 2020 package is a set of binding legislation to ensure the EU meets its climate and energy targets for the year 2020. The use of hydrogen energy should enable to reduce greenhouse gas emissions by $20 \%$ (from 1990 levels), also enable $20 \%$ of EU energy to be renewable, and finally increase the energy efficiency by $20 \%$. Furthermore hydrogen cars have also to be conform to existing legal requirements like measures to prevent and limit waste from end-of-life vehicles (ELVs) and their components and ensure that where possible these are reused, recycled or recovered.

(iii) Concerning the hydrogen technology development, mass-market in hydrogen mobility requires reduced cost of cars and hydrogen fuelling stations. To fulfill this requirement the technology development targets to lower or replace the use of noble materials like platinum in fuel cells and electrolysers. Furthermore the technology development is drawn by the need of higher storage density (meaning higher autonomy range) and simultaneously to obtain lower storage pressures. Today the standardized storage pressure is $35 \mathrm{MPa}$ and $70 \mathrm{MPa}$, the tendency is almost $70 \mathrm{MPa}$ for passenger cars while it is only $35 \mathrm{MPa}$ for buses as reflected by the European directive on the deployment of alternative fuels infrastructure making reference to the technical specification ISO/TS 20100 Gaseous hydrogen-Fuelling stations. While high pressure is important for high energy density it implies high costs related to the compression and high cost regarding the safety requirements 
for high pressure equipment. New storage materials like hydrides or storage vessels working with cryo-compressed hydrogen could lower these costs by maintaining high energy autonomy.

Given the challenges of the hydrogen market for mobility, this article presents a social cost-benefit analysis (CBA) framework to assess the progressive replacement of gasoline ICEV by hydrogen FCV in the European market over the period 2015-2055.

First, we present the social CBA framework in section 2.1. The following sections deal with the assumptions, for hydrogen demand in section 2.2 and supply in 2.3. The economic comparison by the total cost of ownership (TCO) is computed in section 3.1. The section 3.2 presents the external costs such as carbon abatement cost and platinum depletion. The social CBA is performed in section 3.3 providing final results and discussions. Lastly, conclusions are drawn in section 4 .

\section{Materials and Methods}

\subsection{Methodological framework}

The methodological framework is based on the CBA of German market conducted by Creti et al. [7]. They analyze the abatement cost of carbon through FCV and various hydrogen production process and their cost. We extend their analysis to include external costs in Europe, in order to consider the costs and benefits to society as a whole. For this reason, we refer to CBA as social cost-benefit analysis [8]. A social CBA highlights environmentalsocial benefits and costs, and computes in monetary units the impacts on a project, both positives and negatives; these impacts should be appropriately priced.

The social benefits are estimated in terms of carbon prices for three scenarios. We included the carbon abatement cost on the deployment net present values, in order to estimate the share of the transtition costs to hydrogen as an alternative transport fuel that carbon market could finance. Regarding social costs, we consider external costs related to the consumption of non-renewable resources [9] to manufacture fuel cells. Even if platinum loading per FCV has significantly been reduced and platinum recycling rate increases, the demand for this mineral will continue rising [10].

The Figure 1 presents the social CBA framework in terms of underlying assumptions, intermediate values and final results. It is composed of three steps: (i) the economic comparison via the TCO, (ii) the external cost estimation, and (iii) the social-economic comparison (social CBA). The final results consist of two indicators that take into account external costs of car- 
bon abatement and platinum depletion: the social net present value (SNPV) and the year of social conversion.

\subsection{Hydrogen demand of FCV in Europe}

To achieve the economic and social comparison of ICEV and FCV during the period 2015-2055, we assume a complete replacement until 2055 in buying a FCV instead of an ICEV. New acquisitions of passenger light cars (ICEV) in Europe ${ }^{2}$ will be replaced by the FCV following the trends of Energy Technology Perspectives (ETP) 2014 estimated by the International Energy Agency $[12]^{3}$.

The ETP 2014 forecasts the percentage of hydrogen used as alternative transport fuel in Europe, allowing us to estimate the number of FCV during the analyzed period. The demand of FCVs is estimated according the next points: year 2015 is taken as the start time when FCV enters automobile market $[13,14,15]$. The trend is a slow introduction of FCV for the period 2015-2030, followed by an important market share starting around 2035 [16], as predicted by the European projects HyWays [1], POLES model and PROTEC H2 project $[17,18]$. The forecasted hydrogen demand is plotted in Figure 2.

We consider three scenarios ${ }^{4}$ according to the average daily driven distances in different European countries [19]: $80 \mathrm{~km}$ in the "optimistic" scenario; $60 \mathrm{~km}$ in the "moderate" scenario; and $40 \mathrm{~km}$ in the "conservative" scenario.

Other important assumptions are the FCV specifications based on commercial information: (i) a vehicle efficiency of $0.95 \mathrm{~kg} \mathrm{H}_{2}$ per $100 \mathrm{~km}$ in 2015 and of $0.7 \mathrm{~kg} \mathrm{H} \mathrm{H}_{2}$ per $100 \mathrm{~km}$ in 2050 [7], (ii) a driving range of approximately $600 \mathrm{~km}$ per fill-up [20] and (iii) a vehicle lifetime of 10 years.

\subsection{Hydrogen supply and production mix in Europe}

The supply scenario is constructed by two main assumptions. First, the current dominance of steam methane reforming (SMR) process from natural gas will be progresively replaced by cleaner alternatives [21]. The SMR is considered as a transition technology. Secondly, we assume that long-term solutions for hydrogen supply will foster carbon-neutral processes with significant hydrogen production by electrolysis of water using renewable energy sources. The French law [22] is the main driver of this energy transition and

\footnotetext{
${ }^{2}$ There were 11.8 millions of vehicles in 2013 in EU-28 [11].

${ }^{3}$ We work with data that assumes actions to limit global warming to $2{ }^{\circ} \mathrm{C}$.

${ }^{4}$ Poland and Spain are in the first group; Italy, Germany and France in the second; the United Kingdom is in the third.
} 
we assume there will be similar drivers at the European scale. This electrolysis development would be supported by the surplus of European electricity. The optimization of intermittent energy flow generated by renewable sources could be used to reduce electrolysis cost. This production mix was developed during exchanges with experts and industrial leaders during the European project DEMCAMER, see Figure 3.

Five hydrogen production technologies are considered in the present study. The production mix includes: SMR process from natural gas; SMR with carbon capture and storage (CCS); water electrolysis; SMR with biogas and SMR on-site type station. The associated costs are shown in Figure 4.

However, the deployment of hydrogen-based transport raises new challenges for production infrastructures that need to evolve towards flexible small scale on-site production facilities. It is considered that on-site production at the hydrogen refueling stations (HRS) are designed to $50 \mathrm{Nm}^{3} / \mathrm{h}$ of $\mathrm{H}_{2}$, which corresponds to the refilling of 25 vehicles per day [21] and a daily storage capacity of $100 \mathrm{~kg}$ of $\mathrm{H}_{2}$.

The capital cost per HRS with on-site production is expected to decrease from $k € 1500$ in 2015 to $k € 700$ in 2050. Moreover, annual operating and maintenance cost should decrease from $10 \%$ to $8 \%$ of the capital cost [7]. Lastly, the number of HRS is a linear estimation from the hydrogen demand determined for each of the three scenarios. The capital cost includes HRS infrastructure cost and HRS operating and maintenance cost for the period analysed. The capital cost per vehicle is reduced as the fleet of FCV increases.

\section{Results and discussion}

\subsection{Economic comparison of FCV and ICEV}

The economic comparison is evaluated by the TCO method [3]. For the present study, the TCO of the replacement ICEV by FCV considers the costs over the lifetime of a vehicle, including purchase price $\mathrm{Car}_{t}$ (the sum of all costs to deliver the assembled vehicle to the customer) and running cost Run (fuel cost and maintenance cost per vehicle) and infrastructure on HRS. This economic comparison is the difference between buying a FCV including the infrastructure needed and the conventional case of buying an ICEV. We compute the variation of TCO and the investment Inves $_{t}$ on infrastructure for HRS per unit of car in the market, see equation 1.

$$
\Delta \mathrm{TCO}_{t}=\Delta \mathrm{Car}_{t}[\mathrm{FCV}-\mathrm{ICEV}]+\Delta \mathrm{Run}_{t}[\mathrm{FCV}-\mathrm{ICEV}]+\text { Inves }_{t}
$$

The total deployment cost of hydrogen-based transport $\mathrm{DC}_{t}$ is the variation of TCO multiplied by the number of cars. 
Hereafter, the economic comparison is performed by considering the moderate scenario. Firstly, we evaluate the variation of TCO. The delta cost of TCO per vehicle starts at a very high level, around $\mathrm{k} € 49$ in 2015, and progressively drops from $\mathrm{k} € 14$ in 2025 to $\mathrm{k} € 8$ in 2035 and converges in 2052. The infrastructure cost on HRS declines rapidly from $k € 9$ in 2015 to about $\mathrm{k} € 2$ in 2021. The relative high cost of hydrogen production (in 2015: $€ 8$ per $\mathrm{kg} \mathrm{H}_{2}$ by electrolysis and $€ 2.9$ per $\mathrm{kg} \mathrm{H}_{2}$ by SMR from natural gas, see Figure 4) is compensated by the efficiency of FCV. This is an advantage for $\mathrm{FCV}$, considering that gasoline price growth rate decrease from $5.4 \%$ in 2020 , to $3 \%$ in 2040 and $1.5 \%$ in 2050 [23]. Secondly, the main expenses on infrastructure will follow from 2020 to 2035 and then the period 2030 to 2050 will be characterized by significant surplus as the FCV fleet increases. Lastly, the year of economic conversion is the moment at which the total cost of FCV is equal to the total cost of ICEV for the period analyzed. The total cost include infrastructure cost and vehicule lifetime cost and hydrogen production mix. Under the moderate scenario, the cash flow is compensated approximately by 2052. Results of the conservative and optimistic scenarios are detailed in Appendix A.

\subsection{External costs}

\subsubsection{FCV fleet as a carbon abatement option}

The climate change impacts avoided by hydrogen-based transport are evaluated via the abatement cost of carbon. This includes the whole deployment as an investment, spread from 2015 to 2055, in a fleet of hydrogen vehicles that abate emissions. Our aim is to estimate the lowest carbon price needed to make hydrogen FCV profitable.

To evaluate carbon emissions, we use life cycle assessment (LCA) studies $[24,25,26]$ for the emissions of the hydrogen production mix (see Table 1) and emissions of the ICEV ${ }^{5}$. The variation of $\mathrm{CO}_{2}$ avoided per vehicle is estimated. The abatement cost of $\mathrm{CO}_{2}$ for the substitution of all cars is computed by equation 2

$$
\mathrm{AC}_{t}=\frac{\mathrm{DC}_{t}}{\Delta \mathrm{CO}_{2}}
$$

where the abatement cost $\mathrm{AC}_{t}$ is the minimum avoided carbon price for the year $t$ and $\mathrm{DC}_{t}$ is the total deployment cost of hydrogen-based transport.

The carbon price at the end of the period is actualized to 2015 at the social discount rate of $5 \%[27]$.

\footnotetext{
${ }^{5}$ These LCA values are not the most appropriate ones in this specific analysis but they are used as preliminary values because of the lack of European studies. These are values from different literature sources and relevant to the USA context.
} 
Table 1: Carbon emissions of different hydrogen technologies

\begin{tabular}{lc}
\hline $\mathrm{H}_{2}$ technology and transport & $\left.\begin{array}{c}\text { Carbon emissions } \\
(\mathrm{kg} \mathrm{CO} 2 \text { per kg H}\end{array}\right)$ \\
\hline SMR + natural gas & 9.23 \\
SMR on-site & 9.42 \\
SMR + biogas & 2.93 \\
SMR + CCS & 2.54 \\
Electrolysis from renewable energy & 0.00 \\
Pipeline or road transport to market & 1.09 \\
\hline
\end{tabular}

Source: $[24,25,26]$.

Based on the moderate scenario, carbon abatement cost by using FCV is estimated to be approximately $€ 18$ per ton eq. $\mathrm{CO}_{2}$ in 2015 and avoided greenhouse emissions are estimated at 2 millions tons $\mathrm{CO}_{2}$ in 2015. The net present value (NPV) of deployment cost is $€ 382$ millions in 2015 . The results show that a carbon market could finance approximately $10 \%$ of the hydrogen deployment cost. See carbon price estimates for the other scenarios on the supplementary data in the Appendix A.

\subsubsection{Platinum depletion}

We assessed that the required platinum amount could reach nearly 600 metric tons by 2050, which is three times the current platinum supply. It is also expected that insufficient platinum supply and expensive platinum would be a barrier to widespread commercialization of hydrogen FCV [10].

We take into account the scarcity of minerals by measuring platinum depletion. The mineral depletion is the change in stock value of the mineral resources. In the theoretical economic model of increasing scarcity, the mineral depletion is the total rent generated by the natural resource [9]. Mineral depletion is commonly evaluated by the net price method [28]. Moreover, fast growth in demand of minerals results in high estimated scarcity rents to encourage higher primary extraction rates.

Sun et al. [10] analyze the cost of platinum in future FCV considering platinum prices, demand and supply. Each FCV contains approximately from 30 to $40 \mathrm{~g}$ of platinum in 2015. Based on the works of Calle-Vallejo et al. [29], we assume a progressive reduction of platinum use for FCV down to $10-15 \mathrm{~g}$ of platinum in 2050 .

As of today, ICEV consumes $5.6 \mathrm{~g}$ of platinum per vehicle; moreover given the maturity of the technology involved, we expect this quantity to remain 
stable during the analyzed period.

Platinum has a very high recycling rate for different uses in the jewelry, automobile, electronics, chemical industry, petroleum, glass and other industries. The recycling supply creates a counter balance of the depletion effect.

Platinum depletion estimated by net price method is computed as the market price minus the marginal extraction cost of platinum. Alonso [30] analyzed scarcity and recycling rates of platinum over a 50-year period. The net price (platinum depletion) is valued to approximately $2010 € 18$ per gram of platinum extracted, using Alonso [30]'s average estimates: USD 55.6 (2010 $€ 41.94)$ as the market price and USD 31.7 (2010€ 23.91) as the marginal cost of extraction of one gram of platinum. Hence, each gram of platinum extracted is depleting at $2015 € 19.44$.

Platinum depletion is considered constant over the studied period, and represents about $8 \%$ of the deployment cost in 2015 .

Overall, taking into account the carbon abatement cost and the platinum depletion we found that while the former usually gets much more attention than the latter, these two external costs are quantitatively close.

\subsection{Social-economic comparison}

The present social cost-benefit analysis of FCV vs. ICEV provides two main results.

\subsubsection{The year of social conversion}

The economic comparison by TCO converges in 2049 (optimistic scenario) or in 2052 (moderate scenario) or in 2054 (conservative scenario). At this point in time the FCV and ICEV will have the same lifetime cost. This is the first step in the total deployment evaluation.

Next, in each scenario the benefits of carbon abatement by hydrogen vehicles and costs by platinum depletion are integrated for each year.

In conclusion, including external costs enable to save about 10 years in the time needed to reach the conversion time for the full deployment of hydrogen-based transport (see Table 2).

\subsubsection{Social net present value (SNPV)}

Under more ambitious carbon prices estimated by ETP 2015 [31] from 2020 to 2050 (see Table 3), we estimate a social cash flow of introducing FCV to replace ICEV. It includes low and high global marginal abatement costs for $\mathrm{CO}_{2}$ as well as the platinum depletion estimated before.

The social net present values are computed for each scenario over the social discount rate $s$ of $5 \%$ [27]. They represent net savings resulting from 
Table 2: Years of conversion in social cost-benefit analysis of FCV vs. ICEV

\begin{tabular}{lcc}
\hline Scenario & $\begin{array}{c}\text { Economic conversion } \\
\text { (year) }\end{array}$ & $\begin{array}{c}\text { Social conversion } \\
\text { (year) }\end{array}$ \\
\hline Conservative & 2054 & 2046 \\
Moderate & 2052 & 2040 \\
Optimistic & 2049 & 2038 \\
\hline
\end{tabular}

Source: authors.

Table 3: Future $\mathrm{CO}_{2}$ prices in EU-28 ( $€$ per ton eq. $\mathrm{CO}_{2}$ )

\begin{tabular}{lcccc}
\hline & 2020 & 2030 & 2040 & 2050 \\
\hline Low carbon price & 30 & 80 & 120 & 140 \\
High carbon price & 50 & 100 & 140 & 170 \\
\hline
\end{tabular}

Source: [31].

the replacement of ICEV by FCV during the period analyzed. The equation (3) defines SNPV and table 4 summaries the estimates.

$$
\mathrm{SNPV}=\sum_{t=0}^{n} \frac{1}{(1+s)^{t}}\left[(\mathrm{DC})_{t}+\mathrm{AC}_{t} \times\left(\Delta \mathrm{CO}_{2}\right)_{t}-\mathrm{PD}_{t} \times(\Delta \mathrm{Pt})_{t}\right]
$$

Table 4: Social net present value (SNPV) (Millions $€)$

\begin{tabular}{lcc}
\hline Scenarios & Low carbon price & High carbon price \\
\hline Conservative & 3 & 8 \\
Moderate & 20 & 30 \\
Optimistic & 45 & 62 \\
\hline
\end{tabular}

Source: authors.

All external costs are measured under the assumptions of the hydrogen production mix (Section 2.3 and Figure 2).

\subsection{Discussion}

Our work extends [7] in the case of Europe, and includes another external cost (platinum depletion). Creti et al. [7] have shown the impact of carbon 
abatement on the FCV deployment in the case of Germany, they underline that carbon market could partially finance the infrastructure for FCV. We find that the social balance is positive including also platinum depletion, generating net savings for Europe. The Figure 5 plots the carbon abatement cost for two different prices and the platinum depletion vs. the market size of FCV of the moderate scenario.

To extend the present social CBA of hydrogen-based transport, it would also be important to consider other aspects. Air quality in Europe and related health impacts demand ambitious climate policies [32, 33], and air pollution avoided by hydrogen FCV should be included in further social cost-benefit analysis. To reach this objective, it is necessary to make full fuel cycle assessments of different hydrogen production considering the European energy production mix, as performed in the USA routes. The California Energy Commission [34] supported a significant life cycle assessment determined on a "well-to-wheels" basis, which includes fuel production and distribution, fuel cycle emissions and vehicle emissions.

Related to risks, further standardization is also necessary in order to facilitate the introduction of different hydrogen technologies to markets and enable interoperability with the existing infrastructure and appliance providing an enhanced protection of users. This is in the scope of European directive 2014/94/EU on the deployment of alternative fuels infrastructure making technical specifications for hydrogen refueling points for vehicles. Therefore the directive takes reference to several standards actually developed by the CEN 268 WG 5 hydrogen refueling station in order to take into account safety aspects.

This social CBA includes key assumptions that require further attention. Our results are quite sensitive to the hydrogen production mix; extended analysis of other hydrogen production configuration would improve robustness of our model. In addition, other external costs could be evaluated such as noise benefits and social acceptance of hydrogen risks.

\section{Conclusions}

The present study integrates societal benefits for the reduction of greenhouse gas emissions and social costs for the increase of platinum consumption in the manufacture of fuel cells. By including external costs, economic benefits of the replacement of ICEV by FCV were highlighted as well as the generation of positive social net present values

This study suggests that the year of future economic conversion-the profitability horizon - could be shortened by about 10 years. Today, under 
the moderate scenario assumptions, internalizing carbon price could finance approximately $10 \%$ of the hydrogen-based transport from 2015 to 2055 .

European countries have started to internalize externalities for moblity using regulations. Finland and the Netherlands among others reformed existing ad valorem taxes on new cars to affect relative prices of cars by emissions level and to constitute a leverage effect to promote low-emission vehicles [35]. Another initiative is the recent release of the French law on the Energy Transition for Green Growth and the related decree (under preparation) defining the criteria of low-emission vehicles. This decree includes electric battery and hydrogen vehicles.

\section{Acknowledgements}

The authors would like to thank the European Commission $7^{\text {th }}$ Framework program for Research and Technological Development NMP under grant agreement NMP3-LA-2011-262840 (DEMCAMER project) and the French Ministry of Ecology, Energy Transport and Sustainable Development and the Ministry of Research for their fruitful collaborations.

Note: The present paper reflects only the authors' views and the Union is not liable for any use that can be made of the information contained therein.

\section{Appendix A. Supplementary data}

Supplementary data related to this article can be found in the enclosed Excel file. It includes full estimates of the social cost-benefit analysis in the conservative, moderate and optimistic scenarios, as well as platinum depletion estimates.

\section{References}

[1] European Commission. HyWays the European Hydrogen Roadmap. Technical Report April, European Commission, Brussels, 2010. URL http://goo.gl/ZtFB7f.

[2] European Climate Foundation. Roadmap 2050. A practical guide to a prosperous, low-carbon Europe. Technical Report April, 2010. URL http://www . roadmap2050 .eu/.

[3] McKinsey \& Company. A portfolio of power-trains for Europe: a factbased analysis. Technical report, 2010. 
[4] Georg Zachmann, Michael Holtermann, Jörg Radeke, Mimi Tam, Mark Huberty, Dmytro Naumenko, and Anta Ndoye Faye. The great transformation: decarbonising Europe's energy and transport systems. Technical report, Brussels, 2012. URL http://www.fch-ju.eu/sites/ default/files/transformationBP160112.pdf.

[5] European TEN-T. Hydrogen Infrastructure for Transport (HIT), 2014. URL http://www.hit-tent.eu/2014/03/commission-appointseleven-european-coordinators-for-the-new-transportinfrastructure-policy/.

[6] Raimund Bleischwitz and Nikolas Bader. Policies for the transition towards a hydrogen economy: The EU case. Energy Policy, (38):53885398, 2010.

[7] Anna Creti, Alena Kotelnikova, Guy Meunier, and Jean-Pierre Ponssard. A cost benefit analysis of fuel cell electric vehicles. 2015. URL https://medihal archives-ouvertes.fr/INRA/hal-01116997v1.

[8] A. Boardman, D. Greenberg, A. Vining, and D. Weimer. Cost-Benefit Analysis: Concepts and Practice. Pearson Education, 2014. ISBN 9780133794793.

[9] Harold Hotelling. The Economics of Exhaustible Resources. The Journal of Political Economy, 39(2):137-175, 1931. URL http://msl1.mit. edu/classes/esd123/2003/bottles/Hotelling.pdf.

[10] Yongling Sun, Mark Delucchi, and Joan Ogden. The impact of widespread deployment of fuel cell vehicles on platinum demand and price. International Journal of Hydrogen Energy, 36(17):11116-11127, 2011. ISSN 03603199. doi: 10.1016/j.ijhydene.2011.05.157. URL http://dx.doi.org/10.1016/j.ijhydene.2011.05.157.

[11] European Commission. New registrations of passenger cars by type of motor energy and engine size, 2013. URL http://ec.europa.eu/ eurostat/en/web/products-datasets/-/ROAD_EQR_CARM.

[12] IEA. Energy Technology Perspectives, 2014. URL http://www.iea. org/etp/etpmodel.

[13] HyFIVE Project. HyFIVE Project, 2016. URL http://www .hyfive. eu/the-hyfive-project/. 
[14] AVERE France. Projet HyWay : les bons débuts du véhicule électrique à pile à combustible, 2015. URL http://www .avere-france.org/Site/ Article/?article_id=6205.

[15] Meagan Clark. Fuel Cell-Powered Car Push In Europe Rolls Out With 110-Vehicle Project Across The Continent, 2014. URL http://www.ibtimes.com/fuel-cell-powered-car-push-europerolls-out-110-vehicle-project-across-continent-1566845.

[16] Department for Business Innovation \& Skills. Future of hydrogen powered cars mapped out, 2013. URL https://www.gov.uk/government/ news/future-of-hydrogen-powered-cars-mapped-out.

[17] Alain Le Duigou, Marie-Marguerite Quéméré, Pierre Marion, Philippe Menanteau, Sandrine Decarre, Laure Sinegre, Lionel Nadau, Aline Rastetter, Aude Cuni, Philippe Mulard, Loïc Antoine, and Thierry Alleau. Hydrogen pathways in France: Results of the HyFrance3 Project. Energy Policy, 62:1562-1569, nov 2013. ISSN 03014215. doi: 10.1016/j.enpol.2013.06.094. URL http://www.sciencedirect.com/ science/article/pii/S0301421513006010.

[18] Elie Bellevrat, Alban Kitous, and Bertrand Château. The role of Hydrogen in Long-Term Energy System: An Updated Quantitative Analysis with the POLES Model. In International Energy Workshop 2009, volume 2050, 2009.

[19] G. Pasaoglu, D. Fiorello, A. Martino, G. Scarcella, A. Alemanno, A. Zubaryeva, and C. Thiel. Driving and parking patterns of European car drivers: a mobility survey. Technical report, Luxembourg, 2012. URL http://setis.ec.europa.eu/system/files/ Driving_and_parking_patterns_of_European_car_driversa_mobility_survey.pdf.

[20] Hyundai. Hyundai ix35 Fuel Cell to demonstrate real-world benefits to EU decision-makers, 2013. URL http://www.hyundai.co.uk/aboutus/environment/hydrogen-fuel-cell\#technology.

[21] Leonardo Roses, Giampaolo Manzolini, Stefano Campanari, Ellart De Wit, and Michael Walter. Techno-economic assessment of membrane reactor technologies for pure hydrogen production for fuel cell vehicle fleets. Energy and Fuels, 27:4423-4431, 2013. ISSN 08870624. doi: 10.1021/ef301960e. 
[22] L'État Français. Loi no 2015-992 du 17 août 2015 relative à la transition énergétique pour la croissance verte, 2015. URL https://www.legifrance.gouv.fr/affichTexte.do?cidTexte= JORFTEXT000031044385\&categorieLien=id.

[23] European Commission. Consumer prices of petroleum products EU, 2015. URL http://goo.gl/rlo0SI.

[24] William Dougherty, Sivan Kartha, Chella Rajan, Michael Lazarus, Alison Bailie, Benjamin Runkle, and Amanda Fencl. Greenhouse gas reduction benefits and costs of a large-scale transition to hydrogen in the USA. Energy Policy, 37:56-67, 2009.

[25] Ibrahim Dincer. Environmental and sustainability aspects of hydrogen and fuel cell systems. International Journal of Energy Research, (31): 29-55, 2007.

[26] Robert Edwards, Jean-François Larivé, David Rickeard, and Werner Weindorf. Well-to-Wheels analysis of future automotive fuels and powertrains in the European context. Technical report, 2013.

[27] Davide Sartori, Gelsomina Catalano, Mario Genco, Chiara Pancotti, Emanuela Sirtori, Silvia Vignetti, and Chiara Del Bo. Guide to Costbenefit Analysis of Investment Projects. Economic appraisal tool for Cohesion Policy 2014-2020. Technical Report December, European Commission, Luxembourg, 2014. URL http://ec.europa.eu/regional_ policy/sources/docgener/studies/pdf/cba_guide.pdf.

[28] Carmen Cantuarias-Villessuzanne. La mesure économique de la dépréciation du capital minier au Pérou. Phd thesis of economics, University of Bordeaux IV, 2012. URL https://tel archives-ouvertes. fr/tel-00724852/document.

[29] Federico Calle-Vallejo, Jakub Tymoczko, Viktor Colic, Quang Huy Vu, Marcus D. Pohl, Karina Morgenstern, David Loffreda, Philippe Sautet, Wolfgang Schuhmann, and Aliaksandr S. Bandarenka. Finding optimal surface sites on heterogeneous catalysts by counting nearest neighbors. Science, 350(6257):185-190, 2015. doi: 10.1126/science.aab3501. URL http://www . sciencemag. org/content/350/6257/185. abstract.

[30] Elisa Alonso. Material Scarcity from the Perspective of Manufacturing Firms: Case Studies of Platinum and Cobalt. PhD thesis, Massachusetts Institute of Technology, 2010. 
[31] IEA. Framework assumptions ETP, 2015. URL http://www.iea.org/ etp/etpmodel/assumptions/.

[32] Simone Schucht, Augustin Colette, Shilpa Rao, Mike Holland, Wolfgang Schöpp, Peter Kolp, Zbigniew Klimont, Bertrand Bessagnet, Sophie Szopa, Robert Vautard, Jean-Marc Brignon, and Laurence Rouil. Moving towards ambitious climate policies: Monetised health benefits from improved air quality could offset mitigation costs in Europe. Environmental Science \& Policy, 50:252-269, 2015. ISSN 14629011. doi: 10.1016/j.envsci.2015.03.001. URL http://www.sciencedirect.com/ science/article/pii/S1462901115000507.

[33] Artem Korzhenevych, Nicola Dehnen, Johannes Bröcker, Michael Holtkamp, Henning Meier, Gena Gibson, Adarsh Varna, and Victoria Cox. Update of the Handbook on External Costs of Transport. Technical Report 1, RICARDO-AEA, 2014. URL http://ec .europa.eu/transport/themes/sustainable/studies/ doc/2014-handbook-external-costs-transport.pdf.

[34] Sherry Stoner, Tim Olson, McKinley Addy, Rosella Shapiro, B. B. Blevins, James D. Boyd, and Jeffrey D. Byron. Full fuel cycle assessment: well-to-wheels energy inputs, emissions, and water impacts. Technical report, California Energy Commission, California, 2007. URL http://www . energy . ca.gov/2007publications/CEC600-2007-004/CEC-600-2007-004-REV.PDF.

[35] Robin Stitzing. Non-Uniform Ad Valorem Taxation in DifferentiatedProduct Oligopoly: Evaluating a Green Car Tax. In European Association of Environmental and Resource Economists 21st Annual Conference, pages 1-18, Helsinki, 2015. URL http://www.webmeets.com/ eaere/2015/m/viewpaper . asp?pid=1002. 
Figure 1: Social cost-benefit analysis framework FCV vs. ICEV
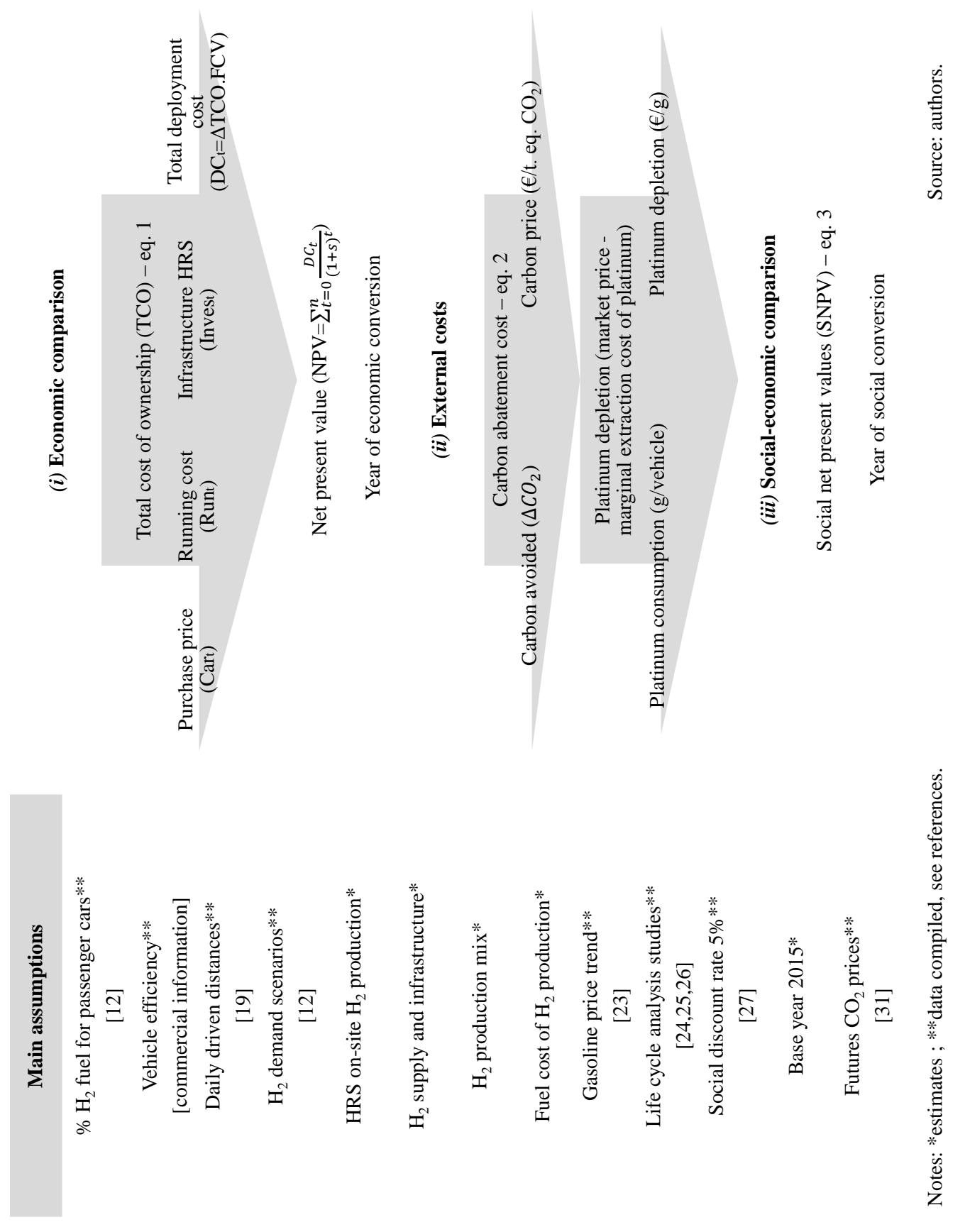
Figure 2: Hydrogen demand to FCV in EU-28

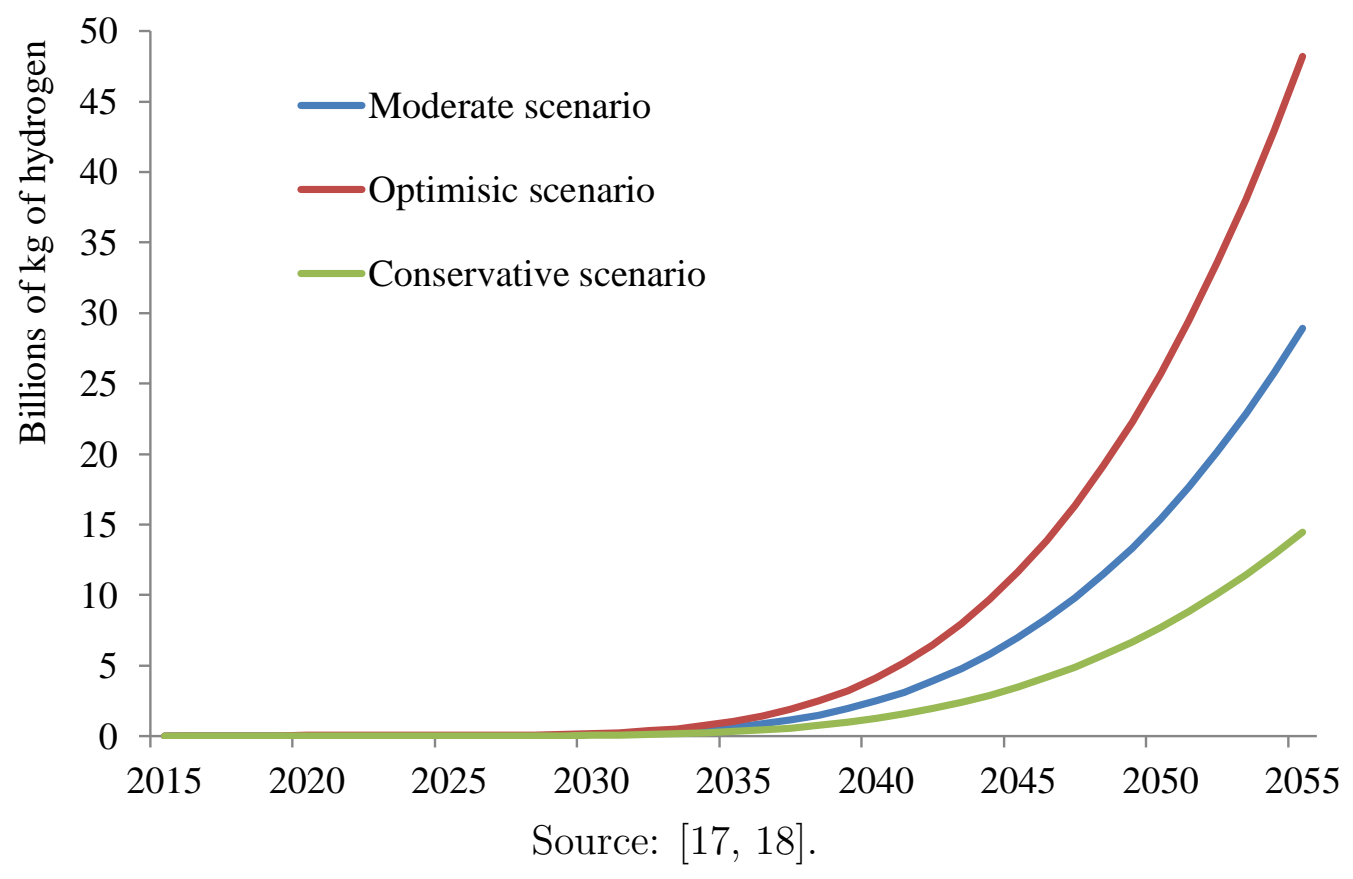

Figure 3: Hydrogen production mix 2015-2055 in EU-28

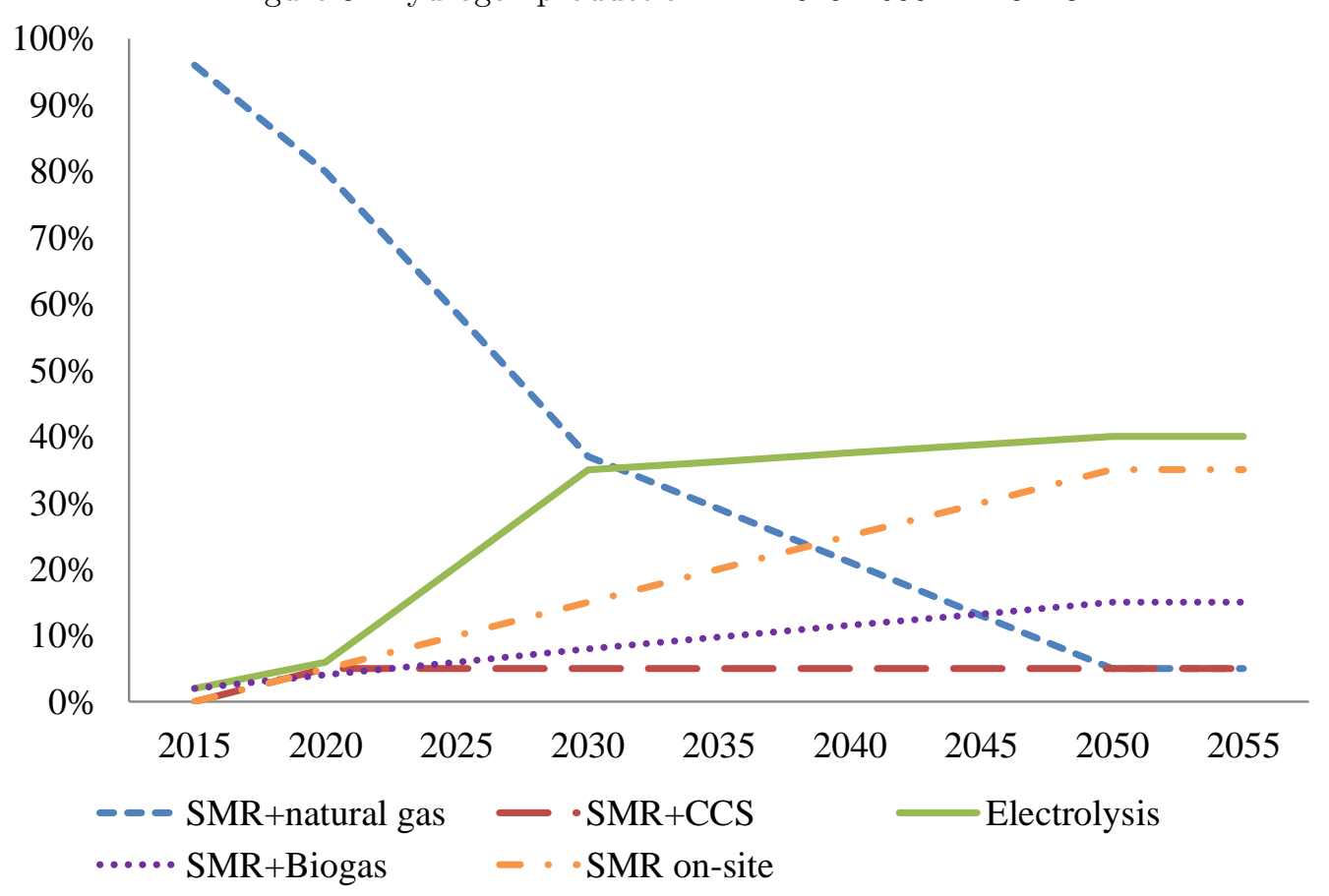

Source: authors. 
Figure 4: Fuel cost by type of hydrogen production $2015-2055$ in EU-28

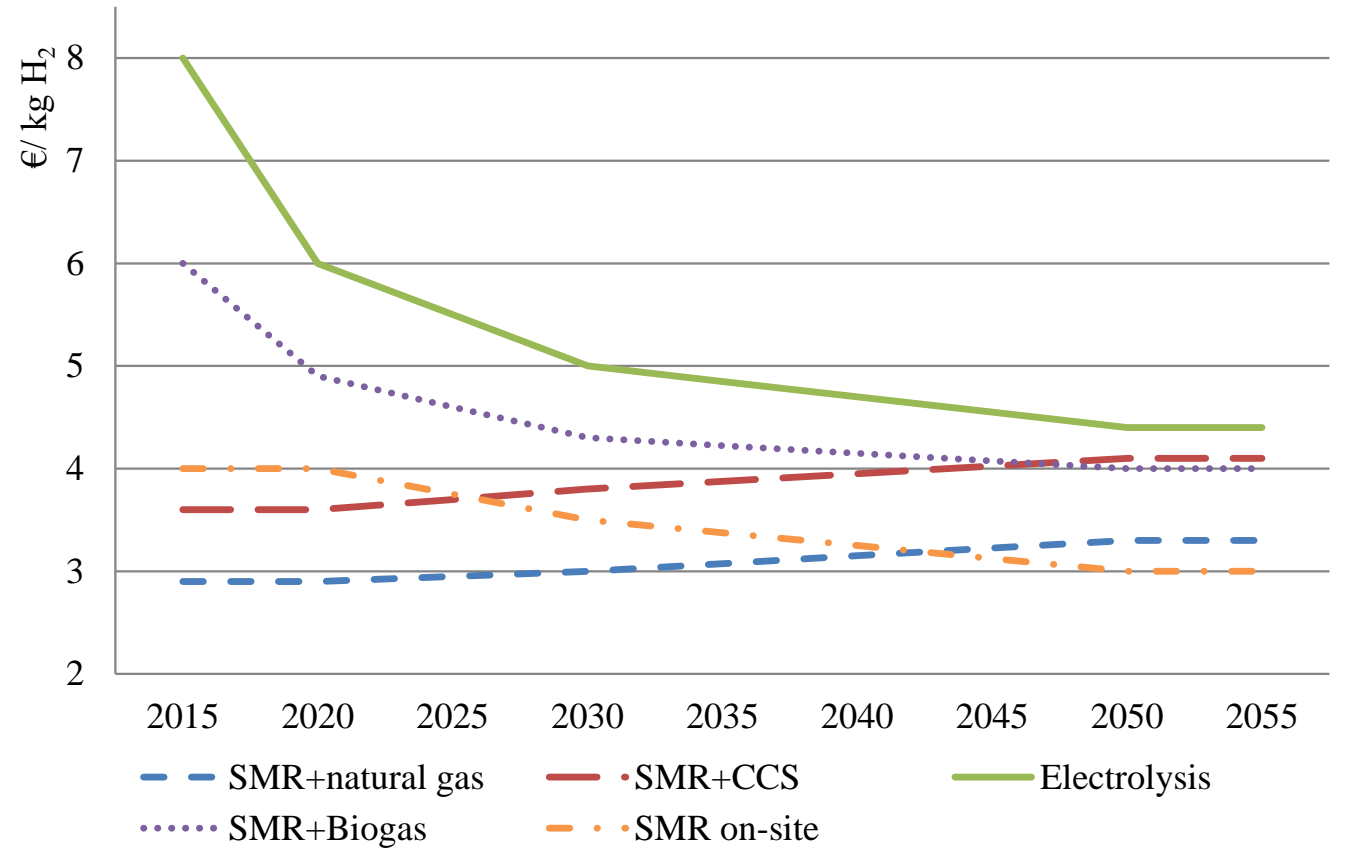

Source: authors. 
Figure 5: External costs in the moderate scenario (millions $2015 €$ )

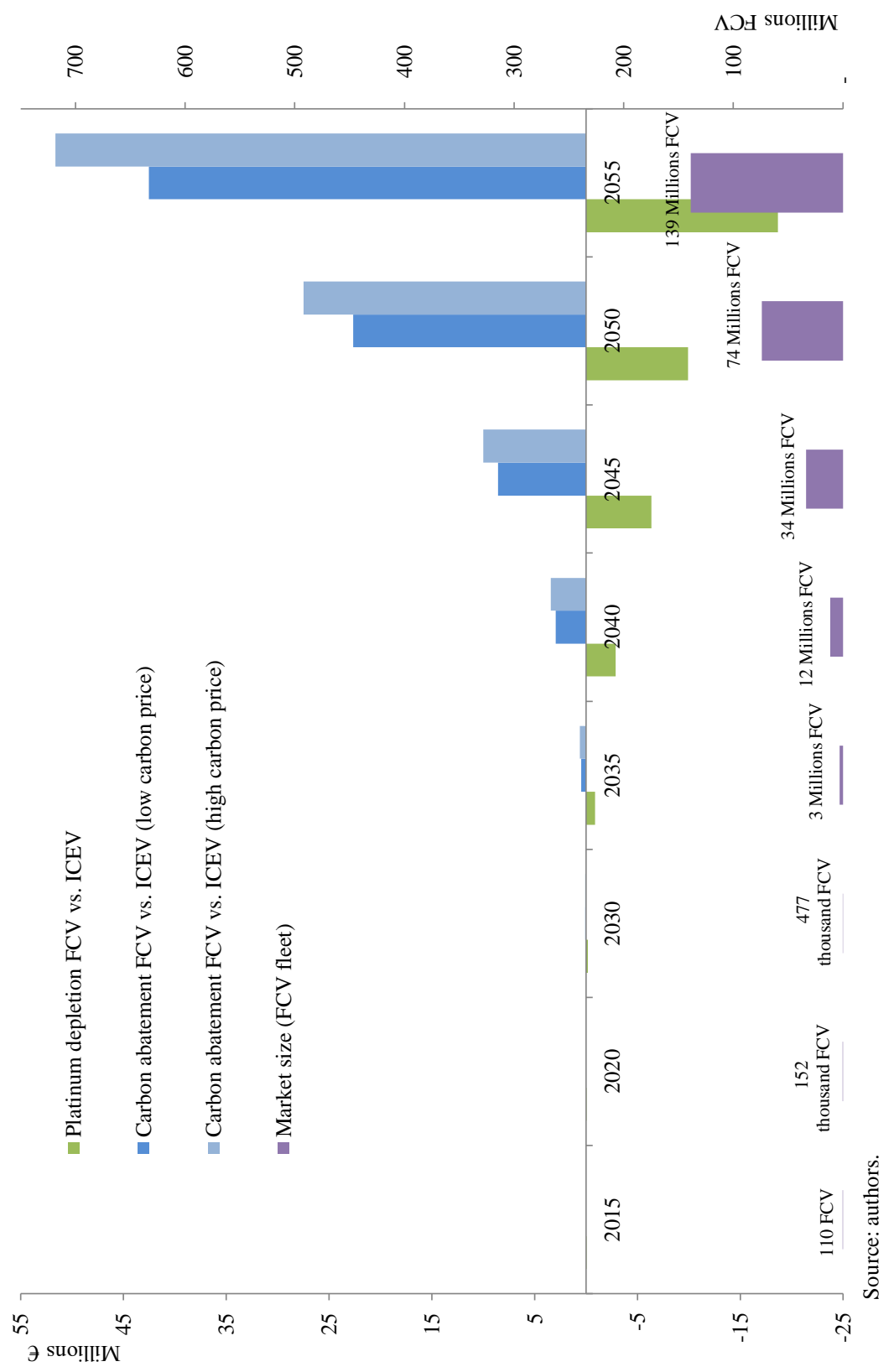

